Kong. Res. J. 1(1) : 54-56, 2014

Kongunadu Arts and Science College, Coimbatore

\title{
TAXONOMIC NOTES ON BOUCEROSIA TRUNCATO-CORONATA SEDGEWICK - A LITTLE KNOWN PLANT SPECIES IN SOUTHERN INDIA
}

\author{
Karuppusamy $^{1 *}$ S., A. Ugraiah ${ }^{2}$ and T. Pullaiah ${ }^{3}$ \\ ${ }^{1}$ Department of Botany, The Madura College, Madurai- 625 011, Tamilnadu. \\ 2,3Department of Botany, Sri Krishnadevaraya University, Anantapur- 515 003, Andhra Pradesh. \\ *E.mail: ksamytaxonomy@gmail.com
}

\begin{abstract}
Boucerosia truncata-coronata Sedgewick is a little known endemic succulent species in southern India. The description of a new species Boucerosia nilagiriana Subba Rao and Kumari from Nilgiri hills make an attention to study the $B$. truncata-coronata. The recent study proved that B. nilagiriana is conspecific to $B$. truncato-coronata. This communication provided detailed description, taxonomic notes and illustration for easy identification and conservation of the little known plant species.
\end{abstract}

Keywords: Taxonomic notes, Boucerosia truncate-coronata, endemic plant.

\section{INTRODUCTION}

The genus Boucerosia Wight belongs to the subtribe Ceropegiae of the family Apocynaceae and comprises about 100 species distributed in Africa, Arabia, Afghanistan, Pakistan, India, Sri Lanka and Myanmar (Plowes, 1995). In India this genus is represented by about 14 species distributed in two distinct centres of distribution: the northern IndoPakistan border areas and southern Peninsular India.

Peninsular India harbours 8 species of Boucerosia, of which B. lasiantha, B. campanulata are synonymised under $B$. umbellata, whereas $B$. nilagiriana and B. crenulata are synonymised under B. truncato-coronata (Meve and Leide, 2002). Of these 8 species, only 5 species are now treated at species level and among them 4 species are confined to the southern India. $B$. umbellata has its distribution extended to Sri Lanka. They occur in narrow isolated habitats especially in arid areas of scrub forests, rocky foot hills and dry lands among the cultivated fields of both in Eastern and Western Ghats slopes. Some of these species are narrow endemic and extremely rare while a few are so far known only from their original descriptions. Boucerosia truncato-coronata is one such little known endemic species which was first described by Sedgewick in 1921 near Hubli in Dharwar district of Karnataka. The type specimen was not preserved in any herbaria and also the protologue has not mentioned any types. Gilbert (1990) designated specimen Sedgwick. s.n. Sept. 1919 from India, Bombay, Dharwar district, Hubli as Lectotype. Gravely and Mayuranathan (1931) have included this taxon in their monograph of Indian Caralluma by quoting Sedgwicks' collection made from areas of Bombay presidency. Later, Kumari and Subba Rao
(1974) have described a new species of Caralluma (Boucerosia) nilagiriana from Nilgiri hills, which is closely related to B. tuncato-coronata. They have collected unflowered specimen from Nilgiri hills and described it after flowering by planting in the garden. It is now treated as synonym for $B$. truncatocoronata. Unfortunately both the specimens are not available in any of the Indian herbaria for further critical studies. After Sedgewick's original report, $B$. trucato-coronata was neither recorded from its original habitat in Dharwar district, nor elsewhere. This perhaps prompted Ahmedullah and Nayar (1987) and Nayar (1996) to categorize this species in danger of extinction in its habitat. The conservation status of this taxon has also not been evaluated so far.

During a recent field survey carried out in connection with a research project on 'Taxonomic survey of Indian genus Caralluma', B. truncatocoronata was collected in Tumkur area of Karnataka, 87 years since its first discovery by Sedgewick in 1921. A small population comprising about 50 individuals was located on rocky boulders among the cultivated lands near Pemmonalli village on the way of Devarayan Durga.

The only source of information available on the morphology and geographical distribution of the species are the original latin description provided by Gravely and Mayuranathan (1931) followed by a brief description in English by Jagtap and Singh (1999). Therefore a more detailed description along with relevant illustration are provided to help easy identification of this little known species.

Boucerosia truncato-coronata Sedgwick, J. Ind. Bot. 2: 125. (1921). Type: Lecto type was designated by Gilbert 1990. B. nilagiriana Kumari \& Subba Rao, 
J. Bombay Nat. Hist. Soc. 73: 199 (1976); Plowes, Haseltonia 3: 59. (1995). B. crenulata (Wall.) Wight \& Arn. Contr. Bot. Ind. 34. (1834). Caralluma truncatocoronata (Sedgwick.) Gravely \& Mayurn. Bull. Madr.Gov. Mus. N. S. 4(1): 21 (1931). (Fig. 1 ).

Plants growing in clumps, up to $15 \mathrm{~cm}$ high, with subterranean runners, spreading by suckers. Branches slender, prostrate, rooting at nodes, not tapering, 4-angled, c. $6 \mathrm{~mm}$ wide, laterally furrowed. Leaves minute, ovate, glabrous, tip acute, arise on the tubercles of the angles. Inflorescence terminal, umbellate, 10-13-flowered. Flowers campanulate, pentagonal, apically flattened in bud. Bracts 2, minute, c. $2.5 \mathrm{~mm}$ long, linear. Bracteoles inconspicuous. Pedicels c. $17 \mathrm{~mm}$ long, green. Calyx divided up to the base, segments 5 , alternating with corolla lobes, c. $4 \mathrm{~mm}$ long, linear, acute, glabrous. Corolla c. $8.5 \mathrm{~mm}$ across, corolla-tube c. $6 \times 6 \mathrm{~mm}$, campanulate, segments 5 , outside green mottled with purple, three distinct colouration on the tube inside, a deep purple ring at the middle with dark purple ring formed a rim of mouth and interior tubes light purple dotted white background with valvate limb, 5-fid, with pellucid glands at bottom. Corollalobes distinct, triangular, acute at tip, dark purple to brownish purple above, a few thin yellow transverse lines interrupted on the lobes, 3 or 4 golden yellow hairs on the margins at the base of corolla lobes. Corona c. $4 \mathrm{~mm}$ in diameter, dark purple; outer corona 5-lobed, truncate tips, lobes prominently cuspidate on either side; inner lobes ligulate, elongate, ascending and appressed on dorsal sulcate surface of anthers; staminal column short, incumbent on the stigma; anthers light yellow, lobes broadly elliptic. Pollinia solitary, erect, yellowish red, compressed, oblong or obtuse, faintly transversely striped, attached laterally to the erect purple corpusculum long, glabrous; stigma 5-angled. Follicle paired, erect, c.5 cm long, lanceolate, glabrous, light purplish streaks above, slightly beaked at the tips.

Flowering \& Fruiting: November - March.

Specimen examined: Karnataka, Tumkur district, Pemmonalli hills, near cultivated lands on the way of Devarayan Durga, S. Karuppusamy and A. Ugraiah 31768 (SKU); Tamilnadu, Coimbatore district, Madhukarai, Kurudimalai, S. Karuppusamy and A. Ugraiah 31733 (SKU).

There are no herbarium specimens in any Indian herbaria except B. nilagiriana Kuamri \& Rao 39262A (CAL), 39262, 39263, 38287 and 37329 (MH). The present collection made after a long gap of type collection approximately $400 \mathrm{~km}$ away from type locality. A fragmented population was observed in about $50 \mathrm{~km}$ surrounding areas of Tumkur district of Karnataka.

Distribution: Karnataka and Tamilnadu.

Uses: Locally this species is used as vegetable as raw material.

\section{TAXONOMIC NOTES ON BOUCEROSIA}

Genus Boucerosia was first discovered in 1834 by Wight and Arnott with flowers in terminal umbels. It was used quite widely for Indian, Arabian and Mediterranian Stapeliad species until N.E. Brown (1892), who included Boucerosia under the genus Caralluma, perhaps overwhelmed by the variety of species being discovered latter in Southern India combined with coronal variations, stem characters, striations and hairiness patterns on flowers. Brown made no attempt to recognize infrageneric groupings of the taxa. Schumann (1895) recognized three sections under Boucerosia which are Eucaralluma (=Caralluma), Lalacruma (=Caralluma gracilis) and Boucerosia, but completely ignored that subgenus Boucerosia is restricted only to Southern India, Sri Lanka and Myanmar.

In southern India, there is only one widespread Stapeliad species viz. Boucerosia umbellata. This species occurs over much of the subcontinent south of Madhya Pradesh including Orissa, Maharashtra, Karnataka, Andhra Pradesh, Kerala, Tamilnadu and also extends to Sri Lanka (Gilbert, 1990). After Brown (1810), the genus has not got any attention of taxonomists, but the first review on Caralluma and its segregates came in 1990 by Gilbert, he has segregated the succulent stemmed stapeliads into three subgenera viz. Caralluma, Urmalcala and Boucerosia. He has enumerated many synonyms for the Boucerosia such as Hutchinia (Wight \& Arnott, 1834), Apteranthes (Miken, 1835), Sarcodon (Brown, 1878), Desmidorchis (Munster, 1990) and Aperanthes (Munster, 1990). Gilbert has considered B. truncatocoronata as a individual species but Plowes (1995) suggested that it is conspecific to B. crenulata. But he noted B. nilagiriana as a synonym for former species. He has given the note for above comment based on J.S. Sarkaria's personal consideration but it has not appeared in any paper.

Recently molecular taxonomic study was conducted on subtribe Ceropegiae by Meve and Liede (2002). They have erected a separate clade for genus Boucerosia, which included only seven taxa and also included another one closely related Indian genus Frerea under Boucerosia. All the above studies of Gilbert (1990), Plowes (1995) and Meve and Liede (2002) have clearly mentioned that Boucerosia 
complex of India must be revised for their taxonomic treatments. The present investigation has concentrated on taxonomic treatment of B. truncatocoronata and also the study reported rediscovery of the same taxon from Karantaka nearly $400 \mathrm{~km}$ far from type locality. Even though Sedgwick has not mentioned precise locality for B. truncato-coronata. According to his description, all the characters coincide with our recently collected specimens.

\section{ACKNOWLEDGEMENT}

The authors sincerely thank the Department of Science and Technology, Government of India for financial assistance to Prof. T. Pullaiah.

\section{REFERENCES}

Ahmedullah, M. and M.P. Nayar, (1987). Endemic plants of Indian region. Botanical survey of India, Howrah, India.

Brown, N.E. (1810), Stapeliae Barklyanae in Hook. Icon. Pl. 20.

Brown, N.E. (1892), Caralluma campanulata N.E.Br. Gard. Chron. 12: 369-370.

Gilbert, M.G. (1990), A review of Caralluma R.Br. and its segregates. Bradleya, 8: 1-32.

Gravely, F.H. and P.V. Mayuranathan, (1931), The Indian species of the genus Caralluma (Fam: Asclepiadaceae). Bull. Madras Museum. 4: 1-28.

Jagtap, A.P. and N.P Sigh,. (1999), Fascicles of Flora of India. Fascicle 24. Botanical Survey of India, Culcutta.

Kumari, G.R. and G.V. Subba Rao, (1976), A new species of Caralluma (Asclepiadaceae) from India. Journal of Bombay Natural History Society 73: 194-196.

Meve, U. and S. Liede, (2002). A molecular phylogeny and generic rearrangement of the stapeliad Ceropegiae (Apocynaceae -
Asclepiadoideae). Plant Syst. Evol. 234: 171209.

Nayar, M.P. (1996). Biodiversity 'Hot spots' of India, Nepal and Bhutan. Tropical Botanical Garden and Research Institute, Thiruvananthapuram, Kerrala, India.

Plowes, C.H. (1995). A reclassification of Caralluma R. Brown (Stapeliae: Asclepiadaceae). Haseltonia 3: 49-70.

Schumann, K. (1895). Asclepiadaceae - Engler and Prantl's Die Naturlichen Pflanzen Familien nebst ihren Gattungen und wichtigeren Arten, insbesondere den Nutzpfanzen, Leipzig. 4: 265278.

Figure 1. Boucerosia truncato-coronat Sedgewick

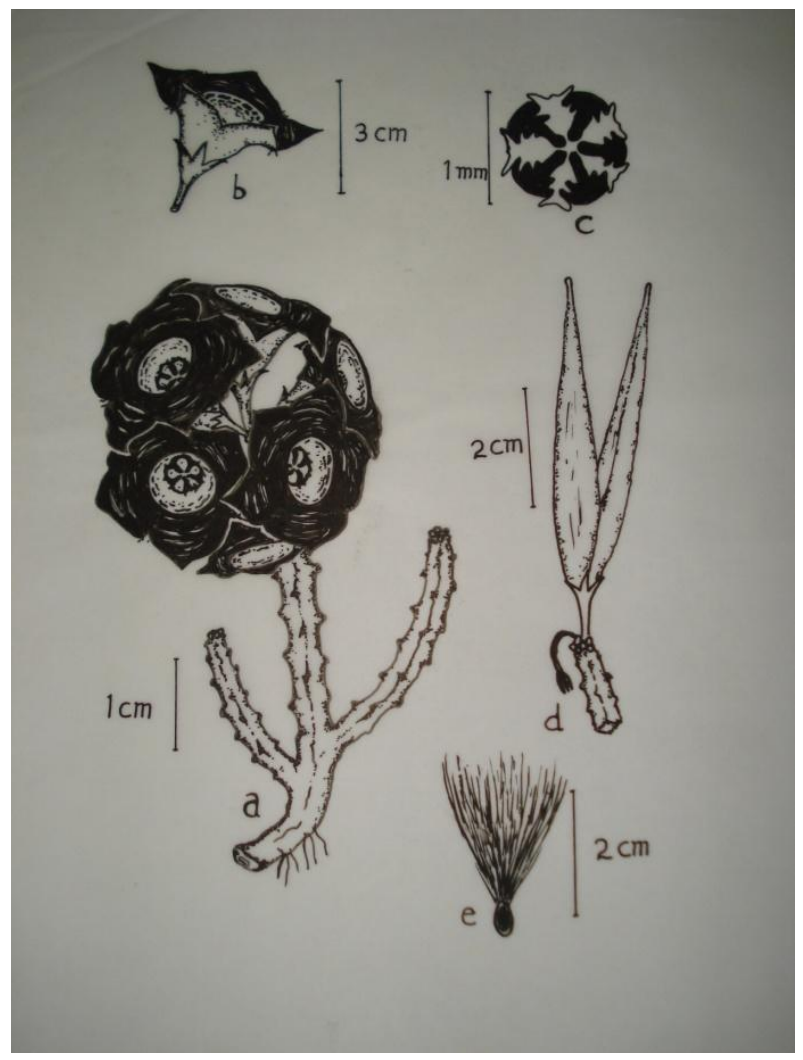

